Dangerous for the security of the economy factors can have an extremely negative impact on the economy of the state, undermining its integrity and sovereignty, from this follows the conclusion that it is necessary to monitor all factors, guided by proven technology. The information function of monitoring is reflected in obtaining data about the position of socio-economic units.

The Russian Academy of Sciences has worked out an enormous number of indicators in various fields of activity - energy, industrial, political, economic, these units have threshold values [6, c.30]. Tracking the evolution of these indicators will allow us to draw conclusions about the state development trend, and to predict the consequences of such development with a view to timely warning of threats.

Security against external and internal threats is a necessary component of an enabling existence, both of an individual and of the state as a whole. The functioning of the state includes many aspects, such as: economic, ecological, social, information, scientific and technological. Economics is the leading sphere of the functioning of the state. Successful economic activity helps to ensure the sovereignty of the state, its integrity. Scientific works help to open this issue most extensively, and the factors that influence it.

The functioning of the state includes many aspects, such as: economic, ecological, social, information, scientific and technological. The economy is the leading sphere of the functioning of the state, so, successful economic activity helps to ensure the sovereignty of the state and its integrity.

$$
* * *
$$

1. $\quad$ 1.B.C. Zagashvili. Economic Security of the Republic of Moldova. II Jurisdiction 1997

2. $\quad$ Senchagov VK Economic security of Russia \. M., "BUSINESS", 2005

3. Petrenko IN Economic security of Russia. Monetary factor. - Moscow: Market DS, 2012.] - $240 \mathrm{~s} /$.

4. Kiyashchenko EA Sociological assessment of the effectiveness of management of social services / EA Kiyashchenko, NV V. Vlasova // All-Russian scientific practical conference on the results of 2014. Materials of the All-Russian practical practical conference on economics and humankind sciences. 2014. P. 86-91.

5. Vassilenok VL, Bykov VN About some threats to economic security of Russia, Moscow, 112000

6. Tilkov, DN "Finansovy monitoring as a kind of state financial control" // Young sc

\title{
Golova I.M., Suhovey A.F. \\ The formation of the innovative ecosystem as a basis for innovative change of Russian regions
}

Institute of Economics of the Ural Branch of Russian Academy of Sciences (Russia, Yekaterinburg)

doi $10.18411 /$ scc-05-2018-25

idsp 000001:scc-05-2018-25

\section{Abstract}

The formation of the innovation ecosystem authors regarded as a modern institutional base of innovative change. There is proposed the technique of substantiation of the outlines of the innovative ecosystem of the region, based on the rating approach. It was developed the method of selecting the perspective directions of the innovation ecosystem of the region, taking into account its production and technological type.

Keywords: priorities for innovative development, the innovation ecosystem, innovative strategy

In modern conditions of innovation becomes a key factor in ensuring the competitiveness of countries and regions in the world markets of goods and services [1]. The need for innovative changes in Russian economy is particularly relevant, because Russia has lagged behind technologically leading countries. Thus, the share of Russia in the global hightech exports is only $0.4 \%$. The self-sufficiency of the Russian market for excavators is now $15 \%-25 \%$ crucibles, equipment for oil-and gas production is $30 \%$ [2]. The negative trend - 
downsizing of research workers is continuing, although in this indicator Russia fall behind advanced countries of West Europe in $1.5-2$ times. The average annual rate of decline of the number of employments in science research in 2000-2016 was $1.3 \%$ [3]. These processes lead to the breach critical for the successful development of the innovation processes of reproduction of scientific personnel.

One of the main reasons for low innovation activity in the high-tech sector is the traditional orientation of State on priority support extractive industries as the main supplier of foreign exchange resources [4]. As a result of production related to hi-tech and high level middle-tech are in unfavorable economic conditions. So, final financial result per employee in manufacturing of electrical, electronic and optical equipment in 2015, was only $4.4 \%$ of the rate for the fuel and energy complex, and in engineering only 1.4\% (calculations based on data of Russian statistics).

Overcoming the current situation requires the transition to a socially responsible innovation policy [5]. An essential prerequisite for successful innovation development, as demonstrated by the world practice is the formation and strengthening of its institutional framework. In this regard, the main challenge for regional innovation policy today, according to the authors, should be the establishment of the innovation ecosystem as a foundation for successful economic development [6].

Under the innovative ecosystems refers to the totality of the conditions for the successful development of innovative activities. Key elements of the innovation ecosystem are researchers and organizations involved in the development of the latest technologies in a specific area of knowledge. The core of the innovation ecosystem is the innovative climate that characterizes the degree of readiness of the region to innovative transformations and is reflected in the condition of scientific, technological and innovation capacity development innovation infrastructure and the effectiveness of innovation policy.

In view of the increasing role and influence the innovation component of the economy a major problem becomes the choice of priorities for the strategy of innovative development of regions.

Long-term strategy of sustainable socio-economic development requires consideration of the problem of the selection of innovation development priorities in a broad context. Along with increased technological independence and competitiveness of the economy of the region, with specific priorities should take into account the issues of improving the quality of human capital. The willingness of the socio-economic sphere to innovate and innovation plays an important role in ensuring the effectiveness of innovative transformations. Its willingness manifests itself primarily in the effectiveness of various forms of support innovation and its subjects from the State and business, in the development of communications, conducive to the spread of promising innovative ideas, and a number of other points. Thus, the choice of priorities for innovation development involves multidimensional prediction of the future of the region as a whole.

The authors of the propose methodology, based on the rating method. During building a formal indicators involved in calculations they take into account the approaches to assessment of innovation as a factor of economic growth used in the methodology of ratings of the WEF's global competitiveness [7], capacity assessment methodology innovative development in different countries and international organizations (European innovation scoreboard [8], the global innovation index [9], etc.), as well as the authors own experience [10].

In order to assess the comparative innovative capacity of regions there are invited to use the corresponding integral indicator.

The index of the innovative capacity takes into account of 4 groups of indicators: 1) level of the science and technology activities in the region; 2) the level of development of innovation; 3) the appropriateness of the overall socio-economic conditions for the development of innovative processes; 4) the level of development of innovation 
infrastructure. The first three groups of indicators characterize the efficiency of functioning of the main elements of the innovation ecosystem in the region. The fourth group reflects the level of favorableness and maturity of the socio-economic situation in the region to implement innovation development paradigm. When calculating the sub indexes and integral index uses standard formula weighted average value of the indicators.

The statistical basis for the calculation of these sub indexes are official data of Russian statistics. Regulation is carried out according to the standard formula: value of indicator by region minus the minimum value of the sample divided by the difference of the maximum and minimum values of this indicator on the regions of the Russian Federation.

Sub indexes are divided into basic, which are taken into account with a weighting equal to unity, and support-with a weighting equal to 0.2. To assess innovation activities in the region as the main are proposed to use indicators such as cost of technological innovation and the production of innovative products, as well as support-share of innovation active enterprises and number of new technologies. Below, the table shows the results of innovative capacity index calculations for the subjects of the Russian Federation, took the first 10 places in the ranking.

In the list of regions-leaders of innovative development of regions were included substantially different on sources of innovation for growth and ability to design and create their own innovative products and services. So, the Tomsk region occupies today on the development of scientific-technical activity in fourth place after the capital of megacities and the Nizhny Novgorod region, but lags far behind them on innovation activity (26-th place among the subjects of the Russian Federation). The strength of the Samara region, which is not an example of more modest development of scientific and technical activities (21, 28 and 52 in Russia respectively), is persistently high innovation activity which is provided, mainly due to the defense sector.

Table

Rating regions innovative capacity index (2016)

\begin{tabular}{|c|c|c|c|c|c|c|c|c|c|c|}
\hline \multirow{3}{*}{$\begin{array}{l}\text { The Subjects of the } \\
\text { Russian Federation }\end{array}$} & \multirow{2}{*}{\multicolumn{2}{|c|}{$\begin{array}{c}\text { Index of } \\
\text { innovation } \\
\text { opportunities }\end{array}$}} & \multicolumn{8}{|c|}{ includingprivateindexes: } \\
\hline & & & \multicolumn{2}{|c|}{$\begin{array}{l}\text { Scientificandte } \\
\text { chnicalactivitie } \\
\text { s }\end{array}$} & \multicolumn{2}{|c|}{$\begin{array}{c}\text { innovationact } \\
\text { ivities }\end{array}$} & \multicolumn{2}{|c|}{$\begin{array}{c}\text { socio- } \\
\text { economicsco } \\
\text { pe }\end{array}$} & \multicolumn{2}{|c|}{$\begin{array}{l}\text { innovationinf } \\
\text { rastructure }\end{array}$} \\
\hline & $\begin{array}{l}\text { The } \\
\text { value } \\
\text { of the } \\
\text { index }\end{array}$ & $\begin{array}{c}\text { Rank } \\
\text { in the } \\
\text { RF }\end{array}$ & $\begin{array}{l}\text { The } \\
\text { value } \\
\text { of the } \\
\text { index }\end{array}$ & $\begin{array}{l}\text { Rank } \\
\text { in } \\
\text { the } \\
\text { RF }\end{array}$ & $\begin{array}{c}\text { The } \\
\text { value } \\
\text { of } \\
\text { the } \\
\text { index }\end{array}$ & $\begin{array}{c}\text { Rank } \\
\text { in the } \\
\text { RF }\end{array}$ & $\begin{array}{l}\text { The } \\
\text { value } \\
\text { of the } \\
\text { index }\end{array}$ & $\begin{array}{l}\text { Rank } \\
\text { in } \\
\text { the } \\
\text { RF }\end{array}$ & $\begin{array}{c}\text { The } \\
\text { value } \\
\text { of } \\
\text { the } \\
\text { index }\end{array}$ & $\begin{array}{c}\text { Rank } \\
\text { in the } \\
\text { RF }\end{array}$ \\
\hline Moscow & 0,62 & 1 & 0,87 & 1 & 0,41 & 8 & 0,50 & 11 & 1,00 & 1 \\
\hline $\begin{array}{ll}\text { Nizhny } & \text { Novgorod } \\
\text { region } & \\
\end{array}$ & 0,55 & 2 & 0,67 & 3 & 0,50 & 4 & 0,58 & 1 & 0,13 & 11 \\
\hline St. Petersburg & 0,51 & 3 & 0,69 & 2 & 0,33 & 12 & 0,53 & 5 & 0,39 & 3 \\
\hline Moscowregion. & 0,50 & 4 & 0,63 & 5 & 0,43 & 5 & 0,40 & 29 & 0,70 & 2 \\
\hline $\begin{array}{ll}\text { The } & \text { Republicof } \\
\text { Tatarstan } & \\
\end{array}$ & 0,46 & 5 & 0,26 & 13 & 0,63 & 1 & 0,52 & 6 & 0,36 & 4 \\
\hline Tomskregion & 0,42 & 6 & 0,64 & 4 & 0,19 & 26 & 0,47 & 15 & 0,24 & 6 \\
\hline PermKrai & 0,39 & 7 & 0,26 & 12 & 0,50 & 3 & 0,48 & 14 & 0,04 & 36 \\
\hline Sverdlovskregion & 0,38 & 8 & 0,31 & 10 & 0,29 & 16 & 0,57 & 3 & 0,29 & 5 \\
\hline Kalugaregion & 0,37 & 9 & 0,44 & 6 & 0,16 & 35 & 0,57 & 2 & 0,15 & 9 \\
\hline Samararegion & 0,35 & 10 & 0,21 & 21 & 0,43 & 6 & 0,46 & 21 & 0,14 & 10 \\
\hline
\end{tabular}

Justification spatial priorities strategy build innovation system requires a more detailed classification of regions for innovation development opportunities. It, except the integral index of innovative features, it is also proposed to take the subindexes of scientific engineering and innovation activity as the most important for assessing the sources of innovation activity region. 
As a subsidiary index of the classification the authors also use indicator, named "index to balance innovation process". It is defined as the ratio of the ranks held by region on subindexes of scientific and innovation activities. If the value of the index is below unit, it means that the level of development of the scientific potential of the region exceeds the level of innovative activity, and place of the region in the ranking is determined by its scientific potential. So, for Moscow index balance innovation process today is 0.13 , and for St. Petersburg-0.17. Abnormally high values of this index indicates an exogenous nature of innovative activity, when it is determined not by the presence on the territory of competitive high-tech industries, and the scale of the construction or modernization production facilities of the mineral complex, amounts of funding from the State budget are situated on the territory of defense enterprises or dislocation in the region "screw-drivers" units of foreign companies. Currently, among the regions of the Russian Federation on this indicator are leaders of the Republics of Mordovia, Tatarstan and Chuvashia.

The approach to classification proposed by authors takes into account the specifics of the sources of innovative activity of regions located at the top of the ratings and more accurately select the most promising ones for forming pillars innovation ecosystem in the country.

Thus, metropolitan regions-Moscow and St. Petersburg by a combined index took first and third place, and on the pillar of scientific and technical activities-first and second places respectively. In terms of the choice of the strategy of innovative development of the format, we can position them as regions-the Federal centers of science and education. Natural place of these regions in the country's innovation system-generator of innovative ideas.

Moscow, Tomsk and Kaluga regions belong to the group of leaders by a combined index of innovation and scientific and technical activity; the index of the balance of the innovation process is between $0.15-1.0$. These regions have maintained traditionally strong scientific potential, have the infrastructure and experience in creating breakthrough innovations. Taking into account these factors and benefits location data regions it is advisable to develop as centers of creating future technologies; development of innovative export-oriented industries and services. Nizhny Novgorod, Samara, Sverdlovsk regions and the Republic of Tatarstan are innovation-active regions with sufficiently strong scientific base and developed complex manufacturing industries. These territories would be the best strategy, focused on the formation of clusters of high-tech and medium-tech industries; centers of advanced technology engineering, metallurgy, chemistry and petrochemistry.

It is known that different levels of production technology have different requirements for State innovation ecosystem of the region as a prerequisite of success. So, for a group of high-tech industries we have our own exclusive developments and technologies, as well as constant involvement in collaborative research projects with scientific organizations of high level of novelty is a mandatory condition of their survival. For extractive industries was sufficient to support innovation at a level which would be in the overall technological trend of their industry, their main interests lie in the field of innovation of middle and low level scientific and technical novelty.

As part of an overall strategy of building the country's innovation ecosystem contours to regions with a high level of development of high-tech industries, it is logical to provide an opportunity to develop their potential as engines of innovation transformations. In this regard, the mission of these regions should be concentrated mainly on strengthening their position as leaders in the field of advanced research and high-tech development focuses on export. This involves emphasis on developing innovative products and technologies, the creation of conditions for basic research and growing civilian high-tech business with priority to support the formation of territories innovative development at leading universities and scientific organizations.

For regions with predominantly medium-tech industries low-level mission innovation system must take into account the needs of the region in the establishment of science and technology and personnel prerequisites to reduce import dependence and timely technicaltechnological modernization of basic production. 
The role of the regions natural resources innovation system as a factor of economic sustainability is substantially lower than in the previous two, and its mission focuses primarily on areas such as increased levels of innovation susceptibility of socio-economic and production scope.

In real life the majority of Russian regions refer to the mixed type. In this case, these regions use a combined strategy, built with the ratio of production-technological enterprises of various types in the structure of the economy and its desired transformations in perspective.

Identified peculiarities of interaction and mutual influence innovation ecosystem of the region and its industrial complex allow to formulate approaches to the choice of spatial priorities of building innovation system in the country, taking into account the needs of specific territories in innovation as a factor in their technical and technological competitiveness.

The article was prepared in accordance with the State job FANO Russia for FGBUN of the Institute of Economics of the RAS on 2018 under the theme of "The development of theoretical and methodological frameworks and methodological tools of development strategies territorial systems of different levels" (GR No AAAA-A16-116031410055-7).

$$
* * *
$$

1. Lenchuk E.B. [Course on the new industrialization-the global trend of economic development] Problemiprognozirovania $=$ Problems of forecasting. 2016, No 3, pp. 132-143. (In Russ.)

2. Filatov V.I. [Import substitution and formation of a new model of economic growth in the Russian economy] VestnicInstitutaeconomikiRossijskojakademiinauk = Bulletin of the Institute of Economics of the Russian Academy of Sciences. 2015, No 2, pp. 76-86. (In Russ.)

3. Todosiychuk A. [About budgetary financing of science and innovation in the medium term] Economist = Economist. 2017, no 2 pp. 43-51. (In Russ.)

4. Inozemtsev V.L. [Seven domestic political constraints of the modernization of Russia] JurnalNovoyeconomicheskoyassotsiatsii = Journal of the new economic association. 2015, No 4, pp. 189194. (In Russ.)

5. Karacharovskiy V. [Two dimensions of technological modernization: on the commercial and social efficiency of the industrial production in Russia] Obschestvo i economika = Society and economy. 2012, No 12, pp. 20-43. (In Russ.).

6. Tsiteladze D.D. [Methodology of creation of self-organizing Russian ecosystems of innovation business] Innovatsii = Innovation. 2011, No 6, pp. 9-18. (In Russ.).

7. The Global Competitiveness Report 2016-2017 /World Economic Forum. Geneva. 2016. 400 p. [Электронный ресурc]. URL: https://www.weforum.org/reports/the-global-competitiveness-report-20162017-1 (дата обращения: 09.08.2017).

8. EuropeanInnovationScoreboard /сайт Комиссии Евросюза [Электронный pecypc]. URL: http://ec.europa.eu/growth/industry/innovation/facts-figures/scoreboards_en (дата обращения: 12.12.2017).

9. The Global Innovation Index 2016: Winning with Global Innovation / Cornell University, INSEAD, and the World Intellectual Property Organization, 2016. - 451 p. [Электронныйресурс]. URL: http://www.wipo.int/edocs/pubdocs/en/wipo_pub_gii_2016.pdf (дата обращения: 01.09.2017).

10. Golova I.M., Sukhovey A.F. [Formation of the innovation component of the region's economic security] Economikaregiona $=$ Economy of the region. 2017. - T.13 (4), pp. 1251-1263. (In Russ.).

\section{Makarenko E., Makarenko T. \\ The need of economic indexes' interpretation from the perspective of managerial accounting \\ Rostov State University of Economics (RINH) \\ (Russia, Rostov-on-Don)}

doi $10.18411 /$ scc-05-2018-26

idsp 000001:scc-05-2018-26

The market of managerial technologies in Russia is still relatively new and thus is receptive to any innovations of its kind. In spite of voluminous scientific and applied research on commercial management the interest to its tools still remains high. The main reason of 